Asian J. Med. Biol. Res. 2016, 2 (1), 62-66; doi: 10.3329/ajmbr.v2i1.27570

\author{
Asian Journal of \\ Medical and Biological Research \\ ISSN 2411-4472 (Print) 2412-5571 (Online) \\ www.ebupress.com/journal/ajmbr
}

\title{
Article \\ A surveillance study on dairy farmers selected in Baghabari milk pocket area of Bangladesh
}

\author{
Md. Nuruzzaman Munsi ${ }^{{ }^{*}}$, Md. Azharul Islam Talukder ${ }^{1}$, Md. Zillur Rahman $^{2}$ and Md. Abu Hemayet ${ }^{1}$ \\ ${ }^{1}$ Goat and Sheep Production Research Division, Bangladesh Livestock Research Institute, Savar, Dhaka 1341, \\ Bangladesh \\ ${ }^{2}$ Training, Palnning and Technology Testing Division, Bangladesh Livestock Research Institute, Savar, Dhaka \\ 1341, Bangladesh
}

${ }^{*}$ Corresponding author: Md. Nuruzzaman Munsi, Senior Scientific Officer, Goat and Sheep Production Research Division, Bangladesh Livestock Research Institute, Savar, Dhaka 1341, Bangladesh. Mobile: +8801717255443; E-mail: nzaman_blri@yahoo.com

Received: 24 February 2016/Accepted: 17 March 2016/Published: 31 March 2016

\begin{abstract}
This study was carried out to reveal the animal agriculture status of the dairy farmers. The survey was conducted by random sampling on 100 dairy farmers (50 from Shahzadpur upazila and 50 from Bera upazila). A pretested questionnaire was developed and multiplied for data collection. The data collected were brought to the headquarters of Bangladesh Livestock Research Institute, Savar, Dhaka for analysis. After analysis it was found that the education level of the farmers of Shahzadpur upazila was better than that of Bera upazila, where $74 \%$ farmers of Shahzadpur and $66 \%$ farmers of Bera were engaged in agriculture. The average annual income and expense of the farmers of Shahzadpur were greater than that of Bera. The average total land, cultivable land and total livestock population per farmer were also higher in Shahzadpur upazila than in Bera upazila. In case of diversity of different genotypes of dairy cattle, except Jersey cross the number of Pabna, Sindhi cross, Shahiwal cross and H-F cross was much greater in Shahzadpur than in Bera. Most of the farmers purchase concentrate feeds and produce roughages in both the locations, where feed scarcity was seen mostly during rainy season. About $56 \%$ farmers treat their cattle with the help of veterinary surgeon and $44 \%$ farmers provide treatment with the help of veterinary field assistant in Shahzadpur, while the scenery was almost opposite in Bera. About 90\% farmers of Bera upazila and 95\% of Shahzadpur upazila used anthelminitics to deworm their animals. Most of the farmers in both sites dewormed their cattle every three months. About $78 \%$ farmers of Shahzadpur and $76 \%$ of Bera vaccinated their animals. About $85 \%$ farmers of Shahzadpur had been found to properly dispose the carcasses, where as only $48 \%$ farmers had been found to do it in Bera. Almost all the farmers washed their hands, equipment and udders of the cows with clean water before milking in both Shahzadpur and Bera. Approximately, all the farmers of both the locations milked their cows twice a day, did not perform milk testing and sold the raw fresh milk to the cooperative societies. All farmers used cow dung as fuel. Overall, it was revealed that Shahzadpur upazila was more advanced than Bera upazila in almost all aspects of animal agriculture.
\end{abstract}

Keywords: baseline survey; dairy farmers; animal agriculture status; dairy cattle; nutrition management; health management

\section{Introduction}

"Human beings are at the centre of concerns for sustainable development. They are entitled to a healthy and productive life in concord with nature" (Report of the United Nations Conference on Environment and Development, Rio de Janeiro, 1992). Food security, nowadays, is the top most global issue considering the expected survival of human beings on the earth. "Food security exists when all people, at all times, have physical and economic access to sufficient, safe and nutritious food that meets their dietary needs and food 
preferences for an active and healthy life" (World Food Summit, 1996). In light of the recent experience in facing food security challenges, Bangladesh requires to enhance agricultural production in order to achieve selfsufficiency in food production. Milk is thought to be a complete food for mankind. On the other hand, dairy cattle rearing can enhance the income of a dairy entrepreneur which improves the livelihood and provide yearround employment of its family labour (Islam et al., 2010). From these points of view, dairy cattle genotypes are important genetic resources to reach the goal. Dairy cattle, one of the most important farm animal genetic resources in Bangladesh, are mainly categorized into two groups- local/native/indigenous and crossbreds of many types (Holstein-Friesian cross, Jersey cross, Shahiwal cross etc). In fact, the population of Bangladesh is growing at alarming rate, whereas the daily requirement of milk per capita is quite greater than its production and supply. Baghabari under Sirajganj district of Bangladesh is highly promising area for the development of dairy industry contributing a lot to the national demand of milk. To set up a profitable dairy industry in this location, selection of a potential genotype of dairy cattle in addition to scientific management of farm is a prerequisite. That is why, emphasis was given to undertake a surveillance study to pick up data on the animal agriculture status of the dairy farmers, the diversity of livestock species, the diversity of different genotypes of dairy cattle, the health and nutritional management practices for the dairy cattle, the milking procedure and cow dung utilization by the farmers.

\section{Materials and Methods}

In this survey study, 100 dairy farmers of two upazilas (50 from Shahzadpur and 50 from Bera) of Sirajganj district were randomly selected. The study was conducted from July/2011 to June/2012.

A standard questionnaire was developed and pretested for which the questionnaires used by Mostari et al., 2008; Uddin et al., 2011; and Islam et al., 2012 were followed partially. The questionnaire included a good number of questions demanding information on education, profession, annual income and expenditure, total land, cultivable land, livestock population, diversity of dairy cattle, feed source, feed scarcity time, treatment process, deworming of cattle, vaccination, carcass disposal, hands and equipment washing, hands and equipment washing material, udder washing, udder washing material, milking frequency, milk testing and milk marketing, use of cow dung by the farmers etc. However, all the questions were made in mother language to best collect the information.

The pretested questionnaire was multiplied through photocopy for data collection. The data were collected by direct interview method. Finally, the data collected were brought to the headquarters of Bangladesh Livestock Research Institute, Savar, Dhaka for analysis with a view to writing a comprehensive report. The descriptive analyses such as sum, average and percentage were performed by using Microsoft Excel computer programme.

\section{Results and Discussion}

The level of education of the farmers of Shahzadpur upazila was better than that of Bera upazila, where $74 \%$ farmers of Shahzadpur and 66\% farmers of Bera are engaged in agriculture (Table 1). So, agriculture was their main income source. The average annual income and expense of the farmers of Shahzadpur were greater than that of Bera (Table 2). The average total land, cultivable land and total livestock population per farmer were also higher in Shahzadpur upazila than in Bera upazila among the selected farmers of this study (Table 3).

Regarding the diversity of different genotypes of dairy cattle, except Jersey cross the number of Pabna, Sindhi cross, Shahiwal cross and H-F cross was much greater in Shahzadpur than in Bera (Table 4). In respect of nutritional management, most of the farmers purchased concentrate feeds and produced roughages in both the locations, where feed scarcity occurred mostly during rainy season (Table 5). Regarding health management of dairy cattle, $56 \%$ farmers treated their cattle with the help of veterinary surgeon and $44 \%$ farmers provided treatment with the help of veterinary field assistant in Shahzadpur, while the scenary was almost opposite in Bera (Table 6). $90 \%$ farmers of Bera upazila and $95 \%$ farmers of Shahzadpur upazila used anthelminitics to deworm their animals (Table 6). Most of the farmers in both sites dewormed their cattle every three months (Table 6). This might be due to their better education level as well as long time cattle rearing experience.

About 78\% farmers of Shahzadpur and 76\% farmers of Bera vaccinated their animals but still $22 \%$ of farmers of Shahzadpur and 24\% farmers of Bera did not use vaccines for their animals (Table 7). But immunizations are an integral part of an effective herd health program. Vaccinations help to curtail the emergence of disease and limit its spread from animal to animal (Bovine Immunization Guidelines, 1993). Uddin et al. (2012) reported that the dairy farmers who used vaccine and medication earned $14.3 \%$ more than those who did not use vaccine and medication. So, an effective vaccination schedule should be designed to be followed by all the farmers. 
Table 1. General information (education, profession) of the dairy farmers.

\begin{tabular}{|c|c|c|c|c|c|c|c|c|c|}
\hline \multirow{2}{*}{$\begin{array}{l}\text { Location/ } \\
\text { Area }\end{array}$} & \multirow{2}{*}{$\begin{array}{l}\text { Farmers } \\
\text { selected }\end{array}$} & \multicolumn{5}{|c|}{ Level of education } & \multicolumn{3}{|c|}{ Profession } \\
\hline & & 1 & 2 & 3 & 4 & 5 & 1 & 2 & 3 \\
\hline Shahzadpur & $\mathrm{n}=50$ & $66 \%$ & $16 \%$ & $10 \%$ & $6 \%$ & $2 \%$ & $18 \%$ & $74 \%$ & $8 \%$ \\
\hline Bera & $\mathrm{n}=50$ & $80 \%$ & $10 \%$ & $4 \%$ & $4 \%$ & $2 \%$ & $28 \%$ & $66 \%$ & $6 \%$ \\
\hline
\end{tabular}

In case of level of education, $\mathbf{1}=$ below SSC, $\mathbf{2}=\mathrm{SSC}, \mathbf{3}=\mathrm{HSC}, \mathbf{4}=$ degree, $\mathbf{5}=$ masters

In case of profession, $\mathbf{1}=$ business, $2=$ agriculture, $\mathbf{3}=$ job

Table 2. General information (annual income and expenditure) of the dairy farmers.

\begin{tabular}{lccc}
\hline Location/Area & Farmers selected & Average annual income (lac) & Average annual expense (lac) \\
\hline Shahzadpur & $\mathrm{n}=50$ & 3.99 & 2.29 \\
Bera & $\mathrm{n}=50$ & 2.26 & 1.34 \\
\hline
\end{tabular}

Table 3. General information (total land, cultivable land, livestock population) of the dairy farmers.

\begin{tabular}{|c|c|c|c|c|c|c|c|c|c|c|}
\hline \multirow{2}{*}{$\begin{array}{l}\text { Locat- } \\
\text { ion/ } \\
\text { Area }\end{array}$} & \multirow{2}{*}{$\begin{array}{l}\text { Farm- } \\
\text { ers } \\
\text { selected }\end{array}$} & \multirow{2}{*}{$\begin{array}{l}\text { Mean total } \\
\text { land } \\
\text { (decimel) }\end{array}$} & \multirow{2}{*}{$\begin{array}{l}\text { Mean } \\
\text { culti- } \\
\text { vable } \\
\text { land }\end{array}$} & \multicolumn{7}{|c|}{ Total livestock population per farmer (mean value) } \\
\hline & & & & Cattle & Buffalo & Goat & Sheep & $\begin{array}{l}\text { Chi- } \\
\text { cken }\end{array}$ & Duck & Pigeon \\
\hline $\begin{array}{l}\text { Shah- } \\
\text { zadpur }\end{array}$ & $\mathrm{n}=50$ & 312.46 & 281.61 & 860 & 0 & 22 & 67 & 89 & 55 & 64 \\
\hline Bera & $\mathrm{n}=50$ & 187.5 & 177.48 & 550 & 0 & 79 & 16 & 209 & 87 & 124 \\
\hline
\end{tabular}

Table 4. Possession of dairy cattle.

\begin{tabular}{llccccc}
\hline Location/ & Farmers & \multicolumn{5}{c}{ Average number of dairy cattle } \\
\cline { 2 - 6 } Area & selected & Pabna & Sindhi X & Shahiwal X & H-F X & Jersey X \\
\hline Shahzadpur & $\mathrm{n}=50$ & 95 & 52 & 101 & 307 & 3 \\
Bera & $\mathrm{n}=50$ & 12 & 6 & 18 & 196 & 141 \\
\hline
\end{tabular}

Table 5. Sources of feed resources and feed scarcity period.

\begin{tabular}{|c|c|c|c|c|c|c|c|}
\hline \multirow{2}{*}{$\begin{array}{l}\text { Location/ } \\
\text { Area }\end{array}$} & \multirow{2}{*}{$\begin{array}{l}\text { Farmers } \\
\text { selected }\end{array}$} & \multicolumn{2}{|c|}{ Source of concentrate } & \multicolumn{2}{|c|}{ Source of roughage } & \multicolumn{2}{|c|}{ Feed scarcity } \\
\hline & & 1 & 2 & 1 & 2 & 1 & 2 \\
\hline Shahzadpur & $\mathrm{n}=50$ & $18 \%$ & $82 \%$ & $80 \%$ & $20 \%$ & $76 \%$ & $24 \%$ \\
\hline Bera & $\mathrm{n}=50$ & $8 \%$ & $92 \%$ & $64 \%$ & $36 \%$ & $92 \%$ & $8 \%$ \\
\hline
\end{tabular}

In case of source of concentrate, $\mathbf{1}=$ self production, $\mathbf{2}=$ purchase

In case of source of source of roughage, $\mathbf{1}=$ self production, $\mathbf{2}=$ purchase

In case of feed scarcity, $\mathbf{1}=$ rainy season, $\mathbf{2}=$ winter

Table 6. Health management (treatment process, deworming) of dairy cattle.

\begin{tabular}{|c|c|c|c|c|c|c|c|c|c|c|c|}
\hline \multirow{2}{*}{$\begin{array}{l}\text { Location/ } \\
\text { Area }\end{array}$} & \multirow{2}{*}{$\begin{array}{l}\text { Farmers } \\
\text { selected }\end{array}$} & \multicolumn{4}{|c|}{ Treatment process } & \multicolumn{2}{|c|}{ Deworming } & \multicolumn{4}{|c|}{ Deworming frequency } \\
\hline & & 1 & 2 & 3 & 4 & 1 & 2 & 1 & 2 & 3 & 4 \\
\hline Shahzadpur & $\mathrm{n}=50$ & $0 \%$ & $56 \%$ & $44 \%$ & $0 \%$ & $98 \%$ & $2 \%$ & $72 \%$ & $12 \%$ & $8 \%$ & $6 \%$ \\
\hline Bera & $\mathrm{n}=50$ & $0 \%$ & $44 \%$ & $54 \%$ & $2 \%$ & $90 \%$ & $10 \%$ & $82 \%$ & $2 \%$ & $4 \%$ & $2 \%$ \\
\hline
\end{tabular}

In case of treatment process, $\mathbf{1}=$ self treatment, $\mathbf{2}=$ treatment given by veterinary surgeon, $\mathbf{3}=$ treatment given by compounder, 4=other ways

In case of deworming, $\mathbf{1}=$ yes, $\mathbf{2}=$ no

In case of deworming frequency, $\mathbf{1}=$ =every 3 months, $\mathbf{2}=$ every 4 months, $\mathbf{3}=$ =every 6 months, $\mathbf{4}=$ every 12 months 
Table 7. Health management (vaccination, carcass disposal) of dairy cattle.

\begin{tabular}{llccccc}
\hline Location/ & Farmers & \multicolumn{2}{c}{ Vaccination } & \multicolumn{3}{c}{ Disposal of carcass } \\
\cline { 2 - 7 } Area & selected & $\mathbf{1}$ & $\mathbf{2}$ & $\mathbf{1}$ & $\mathbf{2}$ & $\mathbf{3}$ \\
\hline Shahzadpur & $\mathrm{n}=50$ & $78 \%$ & $22 \%$ & $84 \%$ & $16 \%$ & $0 \%$ \\
Bera & $\mathrm{n}=50$ & $76 \%$ & $24 \%$ & $48 \%$ & $46 \%$ & $6 \%$ \\
\hline
\end{tabular}

In case of vaccination, $\mathbf{1}=\mathrm{yes}, \mathbf{2}=$ no

In case of disposal of carcass, $\mathbf{1}=$ disposed by burial, $\mathbf{2}=$ disposed on open field, $\mathbf{3}=$ disposed on open water body

Table 8. Practices of hygienic milking of dairy cattle.

\begin{tabular}{|c|c|c|c|c|c|c|c|c|c|c|c|}
\hline \multirow[t]{2}{*}{$\begin{array}{l}\text { Location/ } \\
\text { Area }\end{array}$} & \multirow[t]{2}{*}{$\begin{array}{l}\text { Farmers } \\
\text { selected }\end{array}$} & \multicolumn{2}{|c|}{$\begin{array}{l}\text { Hands and } \\
\text { equipment } \\
\text { washing }\end{array}$} & \multicolumn{3}{|c|}{ Washing material } & \multicolumn{2}{|c|}{$\begin{array}{c}\text { Udder } \\
\text { washing }\end{array}$} & \multicolumn{3}{|c|}{ Washing material } \\
\hline & & 1 & 2 & 1 & 2 & 3 & 1 & 2 & 1 & 2 & 3 \\
\hline Shahzadpur & $\mathrm{n}=50$ & $100 \%$ & $0 \%$ & $96 \%$ & $4 \%$ & $0 \%$ & $96 \%$ & $4 \%$ & $88 \%$ & $0 \%$ & $12 \%$ \\
\hline Bera & $\mathrm{n}=50$ & $96 \%$ & $4 \%$ & $94 \%$ & $4 \%$ & $2 \%$ & $96 \%$ & $4 \%$ & $90 \%$ & $4 \%$ & $6 \%$ \\
\hline
\end{tabular}

In case of hands and equipment washing, $\mathbf{1}=$ yes , $\mathbf{2}=$ no

In case of hands and equipment washing material, $\mathbf{1}=$ water, $\mathbf{2}=$ soap, $\mathbf{3}=$ potassium permanganate solution

In case of udder washing, $1=$ yes, $2=$ no

In case of udder washing material, $\mathbf{1}=$ water, $\mathbf{2}=$ soap, $\mathbf{3}=$ potassium permanganate solution

Table 9. Milking frequency, milk testing and milk marketing.

\begin{tabular}{|c|c|c|c|c|c|c|c|c|}
\hline \multirow{2}{*}{$\begin{array}{l}\text { Location/ } \\
\text { Area }\end{array}$} & \multirow{2}{*}{$\begin{array}{l}\text { Farmers } \\
\text { selected }\end{array}$} & \multicolumn{2}{|c|}{ Milking frequency } & \multicolumn{2}{|c|}{ Milk testing } & \multicolumn{3}{|c|}{ Milk selling } \\
\hline & & 1 & 2 & 1 & 2 & 1 & 2 & 3 \\
\hline Shahzadpur & $\mathrm{n}=50$ & $0 \%$ & $100 \%$ & $8 \%$ & $92 \%$ & $4 \%$ & $0 \%$ & $96 \%$ \\
\hline Bera & $\mathrm{n}=50$ & $2 \%$ & $98 \%$ & $6 \%$ & $94 \%$ & $2 \%$ & $8 \%$ & $90 \%$ \\
\hline
\end{tabular}

In case of milking frequency, $\mathbf{1}=$ once, $\mathbf{2}=$ twice

In case of milk testing, $\mathbf{1}=$ yes, $\mathbf{2}=$ no

In case of milk selling, $\mathbf{1}=$ local market, $\mathbf{2}=$ local trader, $\mathbf{3}=$ cooperative society

Table 10. Use of cow dung by the farmers.

\begin{tabular}{llccc}
\hline Location/ & Farmers & & Use of cow dung \\
\cline { 3 - 4 } Area & selected & Compost & Fuel & Biogas \\
\hline Shahzadpur & $\mathrm{n}=50$ & $0 \%$ & $100 \%$ & $0 \%$ \\
Bera & $\mathrm{n}=50$ & $0 \%$ & $100 \%$ & $0 \%$ \\
\hline
\end{tabular}

Nearly $84 \%$ farmers of Shahzadpur were found to properly dispose the carcasses, where as only $48 \%$ farmers were found to do it in Bera (Table 7). Proper disposal of the carcasses helps to control animal and human disease epidemics. That is why the farmers of both the sites should be more aware of proper disposal of the carcasses which can be obtained through adequate training and mass media propaganda.

Almost all the farmers washed their hands, equipment and udders of the cows solely with clean water before milking in both Shahzadpur and Bera (Table 8). This practice might not significantly reduce the prevalence of mastitis and thus cannot make sure to protect public health. Bacteria in raw milk come from two main sources: organisms transported from the environment into the milking machine and mastitis organisms from within the udder (Taverna et al., 2001; Kelly et al., 2009). Teat skin is a potential reservoir of microbial diversity for milk (Monsallier et al., 2012). Miseikiene et al. (2015) found that the use of udder antiseptics for premilking teats preparation reduced the levels of coliforms, coagulase negative staphylococci and Streptococcus uberis but with exception of iodine, no effect was found on reducing Candida genus yeasts. Therefore, suitable antiseptics should be used by the dairy farmers.

Approximately all the farmers of both the locations milked their cows twice a day, did not perform milk testing and sold the raw fresh milk to the cooperative societies (Table 9). Table 10 shows that $100 \%$ farmers of both Shahzadpur and Bera used cow dung as fuel. Bala et al. (1992) also reported that in different parts of Bangladesh the utilization pattern of cow dung as organic manure was also not uniform and it was being used most inefficiently without exploiting its biogas potential. 


\section{Conclusions}

The present study discloses that between two cattle concentrated sites under Sirajganj district, Shahzadpur upazila was more advanced than Bera upazila in almost all aspects. Therefore, Shahzadpur is a more suitable site to set up a sustainable dairy industry in Bangladesh. Feed scarcity, in this location, is a matter of intervention especially during the rainy season. This problem may be solved by adopting some scientific knowledge based strategies. On the other hand, bio-gas plants should be set up in this highly potential dairy zone to properly utilize the cow dung.

\section{Conflict of interest}

None to declare.

\section{References}

Bala BK, MA Satter and BK Biswas, 1992. Utilization pattern of animal draft power and cow dung in Bangladesh. Bioresour. Technol., 41:1-8.

Bovine Immunization Guidelines, 1993. JAVMA, 203:238-242.

Islam MM, MM Uddin, MN Sultana, M Assaduzzaman and MN Islam, 2010. Distribution pattern and management practices of cross breed dairy cows in cooperative dairy production system in Bangladesh. Livest. Res. Rural Dev., 22: 12-24.

Islam MM, Mohanta UK and Rahman SM, 2012: Study on model livestock community development in selected districts of Bangladesh. Proceedings of Annual Research Review Workshop 2010-11, Bangladesh Livestock Research Institute, Savar, Dhaka 1341, Bangladesh, p. 228.

Kelly P, TK O’Sullivan, DP Berry, SJ More, WJ Meaney, EJ O'Callaghan and B. O’Brien, 2009. Farm management factors associated with bulk tank total bacterial count in Irish dairy herds during 2006/2007. Irish Vet. J., 62: 36-42.

Miseikiene R, J Rudejeviene and G Gerulis, 2015. Effect of pre-milking antiseptic treatment on the bacterial contamination of cow teats' skin. Bulg. J. Vet. Med., 18: 159-166.

Monsallier F, I Verdie-Metz, C Agabriel, B Martin and MC Montel, 2012. Variability of microbial teat skin flora in relation to farming practices and individual dairy cow characteristics. Dairy Sci. Technol., 92: 265278.

Mostari MP, Huque KS, Deb GK, Mufti MMR, Sarker MS, Alam MK and Bostami ABMR, 2008: Breed Survey and Databank Development of Red Chittagong Cattle. Proceedings Annual research review workshop-2008, Bangladesh Livestock Research Institute, Savar, Dhaka 1341, Bangladesh, pp. 4-5.

Report of the United Nations Conference on Environment and Development, Rio de Janeiro, 1992. New York, United Nations Convention to Combat Desertification, 1992.

Taverna MA, LF Calvinho, M Gaggiotti, GA Zimmermann,VR Canavesio, NP Aguirre and R Wanzerried, 2001. Effect of a premilking teat washing system on bacterial contamination of milk. In: National Mastitis Council Annual Meeting Proceedings, Madison, pp. 201-203.

Uddin MT, MM Islam and Nasrin M, 2011. Impact of recent changes in livestock production pattern on farm families' livelihood and health in selected areas of Bangladesh. Bang. J. Liv. Res., 18: 52-69.

Uddin MT, MM Islam and Salam S, 2012. Determination of profitability and coefficients of dairy cattle production in Bangladesh. Bang. J. Liv. Res., 19: 117-119.

World Food Summit, 1996. Rome Declaration on World Food Security. 